\title{
Role of Local Institutions in Rural Tourism Development in Dazhai Community, Guilin, China
}

\author{
Huang LiuMei \\ PhD in College of Public Affairs, Institute of Governance and Rural Development, University of \\ the Philippines( Los Banos), Laguna, Philippines, 4031. \\ Communication author:921749693@qq.com
}

\begin{abstract}
Rural tourism has been proved as an effective approach in many rural areas in China, and during the development processes, local institutions play significant roles in the context of China. This paper is to explore various roles of local institutions in the development of rural tourism in a typical community, Dazhai, in Guilin City. Within its limitations, it examines the roles by identifying the current situations of the community, formal and informal institutions that affect the rural tourism development.Obstacles still exist because of the "top-bottom"political system.
\end{abstract}

Keywords: Dazhai, local institutions, rural tourism, local development

\section{INTRODUCTION}

Rural tourism has been seen an effective approach in China's rural areas. Local institutions play significant role in the development of rural tourism, and it has been argued that the development of rural tourism usually relies on the joint involvement of governments, tourism enterprises, tourists, and local residents(Li,2004; Keyim, 2012).

Due to the traditional "top-bottom" political system under the context of China, the local institutions act as different roles in the dimensions of political, economy, culture, society and environment. And achievements have been achieved in recent years. However, limitations can also be seen under this kind of "centralization", which gives little space for the local community and its members. This paper choose the typical site, Dazhai community in Guilin city for study. The following figure implies the location. 


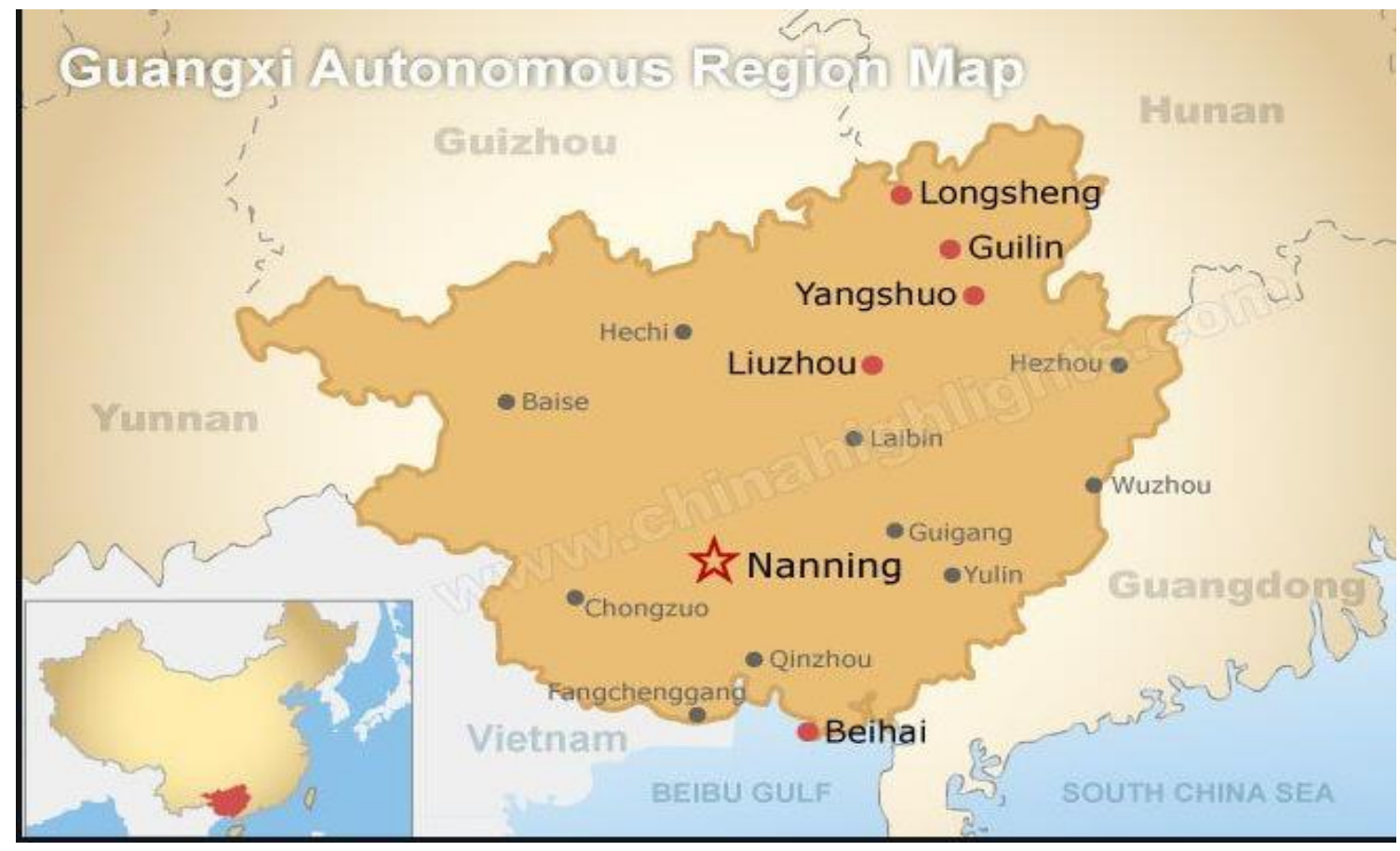

Figure 1. The location of the Dazhai Community.

Source: China Discovery (2020)

Dazhai, the once extremely impoverish community in Guilin, has successfully gotten rid of poverty by rural tourism development in recent years. The community started tourism development since 1975, which appeared as non-profitable sight viewing and the villagers got some tips from the visitors and the visitors' photos were the only publicity at that time. It normally begins rural tourism in 2003, tourists and the collective benefits as well as the villagers' dividends increased year by year.

The purpose of this paper, is to investigate and evaluate the various roles played by the local institutions in the development of rural tourism in Dazhai and to set a proper the institutional framework and ensure the consistency and effective implementation of the overall development policy (OECD, 2009).

\section{LOCAL INSTITUTIONS, RURAL TOURISM AND LOCAL DEVELOPMENT}

\section{Local Institutions and Rural Tourism}

Institutions are the structure that humans impose on human interaction and therefore define the incentives that (together with the other constraints (budget, technology, etc.) determine the choices that individuals make that shape the performance of societies and economies over time(North,1990).Institutions consist of formal rules, informal constraints (norms of behavior, conventions, and self imposed codes of conduct) and the enforcement characteristics of both. The degree to which there is an identity between the objectives of the institutional constraints and the choices individuals make in that institutional setting 
depends on the effectiveness of enforcement. Institutions affect economic performance by determining (together with the technology employed) transaction and transformation (production) costs. Thus institutional changes can be an essential step to further progress in economic history and economic development.

The process of change is overwhelmingly incremental(North,1990). The reason is that the economies of scope, the complementary, and the network externality that arise from a given institutional matrix of formal rules, informal constraints, and enforcement characteristics will typically bias costs and benefits in favor of choices consistent with the existing framework.

Formal and informal institutions embedded in the development of rural tourism

Changes in the formal rules may come about as a result of legislative changes such as the passage of a new statute, of judicial changes stemming from court decisions that alter the common law, of regulatory rule changes enacted by regulatory agencies, and of constitutional rule changes that alter the rules by which other rules are made.

While changes in informal constraints are norms, conventions, or personal standards of honesty, for example--have the same originating sources of change as do changes in formal rules; but they occur gradually and sometimes quite subconsciously as individuals evolve alternative patterns of behavior consistent with their newly perceived evaluation of costs and benefits.

According to North(1990), "If institutions are the rules of the game, organizations are the players". They are groups of individuals engaged in purposive activity provide a settled plan of self government for the proposed settlers (Hughes, 1987). There could be two kinds of institutional arrangements: the vertical and the horizontal(North,1990).Vertical linkage was thus a contributing factor to multidimensional success in rural development. Similarly, but even more strongly, horizontal linkage with organizations at the same level contributed to better rural local organizational performance. A combination of horizontal and vertical linkage added to this effect. Also, there can be certain linkage between the rural community and local institutions, which can be reflected as formal and informal institutions that refer to visions, shared norms, agreed rules and behaviors.

\section{Rural Tourism and Local Development}

Rural tourism has been taken as effective approach for poverty alleviation and local development. However, it has been greatly affected by the traditional "top-down" political system in the context of China. A driving force could be established towards local development by local institutions and local community, forming a "sense of shared ownership" and become "managers" of their development initiatives. Through a collaborative partnership in undertaking the responsibility for developing a local "vision" and strategy; and designing planning, allocating resources, implementing and monitoring/evaluating of development activities that would better cater the local needs. It analyzed the cases of a typical ethnic community in Guilin, China, discussed the roles of local institutions and the features on administrative-political boundaries.

General rural development needs genuine decision-making authority to represent a local constituency to address the need for coordination and integration, which can lead to 
a return to centralized planning and work against effective local institutions for communitydriven initiatives.

\section{METHODOLOGY}

This research used the single-case study design and employed both qualitative and quantitative research methods of data collection, analysis, and interpretation. Case study is a form of qualitative research method in depth rather than breadth which examines a social unit, be that a person, a family, an institution or even the entire community in order to illuminate previously hidden issues (Flyvbjerg, 2006). Zainal (2007) defined the case study method that enables a researcher to closely examine the data within a specific context. Further, case studies, in their true essence, explore and case study as a research method investigate contemporary real-life phenomenon through detailed contextual analysis of a limited number of events or conditions, and their relationships.

Both primary and secondary data and quantitative and qualitative and were collected, analyzed and interpreted in this research. According to Yin (1984 as cited in Zainal 2007) multiple sources of information is being used because limiting to only quantitative method would obscure some of the important data that need to be uncovered in studies. Zainal (2007) stated that detailed qualitative accounts often produced in case studies not only help to explore or describe the data in real-life environment, but also help to explain the complexities of real-life situations which may not be captured through experimental or survey research.

Of the total 275 households, a total of 150 respondents. These respondents were purposively selected to represent the local residents who are involved in tourism in Dazhai. The researcher selected some stakeholders making sure the community will be represented equally. Key stakeholders such as project implementers, extension workers, municipal tourism officers in the location of the study site were also be selected serving as key informants.

\section{FINDINGS AND DISCUSSIONS}

\section{An Overview of Dazhai}

Dazhai is located in the northeast of Guilin, Longji Town, Longsheng Autonomous County, famous for the Longji Terraces Scenic Area. It is very accessible by National Highway No.321. Terraced fields of Dazhai and Ping'an are the core of Longji Terraced Fields. It integrates natural ecological sightseeing, folk cultural experience, leisure and vacation, with a total area of 70.16 square kilometers. Compared with other villages in Longji Terraces, Dazhai's terraced landscape is the most distinctive with rich human resources and sound environment. The whole community governs six natural villages: Tiantou, Zhuangjie, Dazhai, Xinzhai, Damaojie, and Dahushan. In 2003, Guilin Longji Tourism Co., Ltd. and Dazhai community jointly developed the Jinkeng Terraced Field Scenic Area. After the opening of the highway, accessibility of the scenic spot has been greatly improved. Strong potential has been stimulated by tourism development and has changed the economic backwardness and the low living standards to a certain extent. 


\section{Main Attractions in Dazhai}

Longsheng County has comparative advantage in tourism, largely linked to its mountainous topography and altitude as well as its minorities' culture. Dazhai, as one of the villages, has unique topography, folk culture and natural attractions. It benefits from a range of natural attractions that are of potential advantage in growing tourism as a major sector of the economy.

Documents at the national, provincial, and municipal governments show that the numerous features, including natural scenery like mountains, landscapes, water, and cultural, and historical attractions. Key tourism features of Longsheng resulted from its natural high-altitude mountainous topography, and its minorities' cultural and historical custom, especially the terraces. The Longji Terrace in Dazhai is regarded as one of Guilin's highest must-visit destinations. With the its natural hot springs, clean mountain air, the development of health and wellness resorts are also products which are targeted for attractions (Table 1).

Dazhai's attractions are also rural villages and people as well as minorities' culture nd customs. The communities do not only possess the indigenous knowledge systems they have used for generations to preserve the traditions, but through their unique culture and heritage they are also part of the attractions that draw tourists to the village (Manwa, 2012). Architectures and crafts, especially the minorities' long hair with Guinness World Record, as well as the daily life itself in the village, like planting, weaving, costumes and minorities' festivals. There was only one path which is made from stones and with its long history the village takes it for the only way to communicate with the externals.

\section{Table 1. Main attractions in the Dazhai community}

\begin{tabular}{|c|c|c|}
\hline TYPES & FEATURE & DESCRIPTION \\
\hline $\begin{array}{l}\text { World } \\
\text { agricultural } \\
\text { heritage }\end{array}$ & $\begin{array}{l}\text { With a long history of more than } \\
2,300 \text { years; representing } \\
\text { Guilin's or China's image and } \\
\text { marketability }\end{array}$ & Terraces scenic spots area \\
\hline \multirow[t]{2}{*}{$\begin{array}{l}\text { Natural } \\
\text { landscape }\end{array}$} & $\begin{array}{l}\text { Beautiful and unique } \\
\text { landscapes; natural history and } \\
\text { wilderness; a sense of } \\
\text { remoteness; }\end{array}$ & $\begin{array}{l}\text { Highland basalt massif. Longji (meaning } \\
\text { Dragon and the backbones) terraces are like } \\
\text { dragon backbone, dating back to Ming and } \\
\text { Qing dynasty; }\end{array}$ \\
\hline & $\begin{array}{l}\text { Terraces are most valued by } \\
\text { tourists and photographers, } \\
\text { regarded as the core of the } \\
\text { scenic spots }\end{array}$ & Natural hot springs. \\
\hline \multirow{2}{*}{$\begin{array}{l}\text { Farming } \\
\text { cultural } \\
\text { heritage }\end{array}$} & $\begin{array}{l}\text { Aesthetically pleasing aspects in } \\
\text { ancient farming civilization; }\end{array}$ & $\begin{array}{l}\text { Ou-geng farming techniques (couples } \\
\text { plowing); }\end{array}$ \\
\hline & $\begin{array}{l}\text { Unique primitive farming } \\
\text { techniques; }\end{array}$ & $\begin{array}{l}\text { Officially included in the } 2 \text { nd batch of China's } \\
\text { important agricultural and cultural heritage in }\end{array}$ \\
\hline
\end{tabular}




\begin{tabular}{|c|c|c|}
\hline TYPES & FEATURE & DESCRIPTION \\
\hline \multirow{7}{*}{$\begin{array}{l}\text { Minority } \\
\text { Ethnic } \\
\text { culture }\end{array}$} & \multirow[b]{2}{*}{$\begin{array}{l}\text { Based on the natural ecological } \\
\text { environment, using traditional } \\
\text { farming techniques to integrate } \\
\text { into the farming customs, } \\
\text { agricultural beliefs, and } \\
\text { management systems, driven by } \\
\text { the residents' wisdom and } \\
\text { creativity. }\end{array}$} & 2014 \\
\hline & & $\begin{array}{l}\text { Officially honored as rice terrace system in } \\
\text { Southern China (one from four) on the list of } \\
\text { important global agricultural and cultural } \\
\text { heritages by the Food and Agriculture } \\
\text { Organization (FAO) in } 2018 \text {. }\end{array}$ \\
\hline & \multirow{5}{*}{$\begin{array}{l}\text { Cultural Identity of the People; } \\
\text { Minorities' culture, architecture, } \\
\text { and crafts; } \\
\text { Original ecological culture of } \\
\text { Miao, Yao, Dong, and Zhuang } \\
\text { minorities (well preserved in this } \\
\text { area with special folk customs } \\
\text { and ethnic culture). }\end{array}$} & $\begin{array}{l}\text { Minorities' long hair with Guinness World } \\
\text { Record (since ancient times, local minority } \\
\text { women have a tradition of keeping long hair, }\end{array}$ \\
\hline & & $\begin{array}{l}\text { symbolizing long life, wealth, auspiciousness } \\
\text { and beauty. The age of } 17 \text { is the only time for } \\
\text { a haircut in their life). }\end{array}$ \\
\hline & & $\begin{array}{l}\text { The local architecture (a typical wooden- } \\
\text { fence building with three floors: the bottom is } \\
\text { for livestock and the upper twos for living). }\end{array}$ \\
\hline & & $\begin{array}{l}\text { Ethnic performances like bamboo pole } \\
\text { dance, lion dance, board shoe dance, etc. } \\
\text { are all intangible cultural heritage; }\end{array}$ \\
\hline & & $\begin{array}{l}\text { Daily life, like planting, waving, costumes, } \\
\text { and ethnic festivals. }\end{array}$ \\
\hline \multirow[t]{2}{*}{ Special diets } & \multirow{2}{*}{$\begin{array}{l}\text { A line of famous and special } \\
\text { minority diets and has formed a } \\
\text { good situation for the } \\
\text { comprehensive advancement of } \\
\text { various industries, prompting a } \\
\text { fundamental change in the local } \\
\text { people's thinking and concepts. }\end{array}$} & $\begin{array}{l}\text { Four Treasures of Longji (fragrant glutinous } \\
\text { rice, water wine, cloud tea, and chili). }\end{array}$ \\
\hline & & $\begin{array}{l}\text { Special dishes cooked in bamboo-like slip } \\
\text { chicken rice, eighteen stuffed rice, Longji } \\
\text { chicken, farm smoked bacon, fried eggs with } \\
\text { bamboo shoots, farm camellia, and other } \\
\text { specialties, and wines made from fruits or } \\
\text { grains. }\end{array}$ \\
\hline \multirow{3}{*}{$\begin{array}{l}\text { Agriculture } \\
\text { and forestry } \\
\text { products }\end{array}$} & \multirow{3}{*}{$\begin{array}{l}\text { Prosperity for all-round } \\
\text { development of ecological } \\
\text { forestry, agriculture, and } \\
\text { environmental-friendly } \\
\text { processing industry. }\end{array}$} & $\begin{array}{l}\text { Health medicine; Medical shampoo; } \\
\text { Medicinal baths }\end{array}$ \\
\hline & & $\begin{array}{l}\text { Ethnic embroidery crafts; Bamboo and } \\
\text { carving; Ethnic silverware }\end{array}$ \\
\hline & & Longji water wine; Tea oil. \\
\hline
\end{tabular}

Source: Personal interviews

After almost 20-years of tourism development, Dazhai has been transformed from an impoverished mountain village into a national 4A-level scenic spot and a world-renowned terraced tourist attraction. As such, the Guangxi province, the Guilin City, and the Longsheng Country for which Dazhai community is administratively under have received national, provincial, and municipal awards. At the same time, the scenic spot was also 
granted as "globally important agricultural cultural heritage", a national 4A-level scenic spot, national agricultural tourism pilot, and a national wetland park and many other honors (Table 2). One of the highest honors received was the Global Important Agricultural Cultural Heritage (Guangxi Longsheng Longji Terraced Field System) which was awarded by the Food and Agriculture Organization (FAO). The current thrust toward creating a national 5A-level tourist attraction.

Table 2. List of honors won by the Longji Scenic Area

\begin{tabular}{|c|c|c|c|}
\hline $\begin{array}{l}\text { YEA } \\
\mathbf{R}\end{array}$ & NAME & LEVEL & AWARDING BODY \\
\hline 1988 & Longji Scenic Spots Area & Provincial & Guangxi Admin Memo No. 97 \\
\hline 2004 & $\begin{array}{l}\text { China Rice Culture and } \\
\text { Science Base }\end{array}$ & National & $\begin{array}{l}\text { Chinese Folk Artists Association of } \\
\text { Rice Culture Major Committee }\end{array}$ \\
\hline 2006 & $\begin{array}{lr}\text { National } & \text { Agricultural } \\
\text { Tourism Demonstration Site }\end{array}$ & National & $\begin{array}{l}\text { National Industrial and Agricultural } \\
\text { Tourism Demonstration Committee }\end{array}$ \\
\hline 2007 & $\begin{array}{l}\text { Chinese classic village } \\
\text { landscape (Dazhai) }\end{array}$ & Provincial & $\begin{array}{l}\text { Secretary-General of the Chinese } \\
\text { Society of Land Economics and } \\
\text { Ancient Village Protection and } \\
\text { Development } \\
\text { Committee }\end{array}$ \\
\hline 2007 & $\begin{array}{l}\text { Top Ten Famous Villages of } \\
\text { Leisure Agriculture in } \\
\text { Guangxi (Dazhai) }\end{array}$ & National & $\begin{array}{l}\text { Guangxi } \quad \text { District } \quad \text { Agriculture } \\
\text { Department }\end{array}$ \\
\hline 2008 & $\begin{array}{l}\text { Chinese Landscape Village } \\
\text { (Jinzhu Village) }\end{array}$ & National & $\begin{array}{l}\text { Ministry of Housing and Urban-Rural } \\
\text { Development, with Ministry of } \\
\text { Tourism }\end{array}$ \\
\hline 2010 & $\begin{array}{l}\text { Top Ten Rural Agricultural } \\
\text { Tourism Pilot villages } \\
\text { (Ping'an and Dazhai ) }\end{array}$ & Municipal & Guilin Tourism Bureau \\
\hline 2010 & $\begin{array}{l}\text { Longji National AAAA Level } \\
\text { Scenic Spot }\end{array}$ & National & $\begin{array}{l}\text { National Tourism Scenic Area } \\
\text { Quality Rating Committee }\end{array}$ \\
\hline 2012 & $\begin{array}{lll}\text { Famous } & \text { National } & \text { Scenic } \\
\text { Tourism } & \text { Village } & \text { (Longji } \\
\text { Village) } & & \end{array}$ & National & $\begin{array}{l}\text { Ministry of Housing and Urban-Rural } \\
\text { Development, with Ministry of } \\
\text { Tourism }\end{array}$ \\
\hline 2014 & $\begin{array}{l}\text { Top Ten Landscapes of } \\
\text { Terraced Fields in "Beautiful } \\
\text { Countryside in China" }\end{array}$ & National & Ministry of Agriculture \\
\hline 2014 & $\begin{array}{lr}\text { China's } & \text { important } \\
\text { agricultural, } & \text { cultural } \\
\text { heritage } & \end{array}$ & National & $\begin{array}{l}\text { Ministry of Agriculture, with Ministry } \\
\text { of Tourism }\end{array}$ \\
\hline 2016 & $\begin{array}{lr}\text { National } & \text { Research and } \\
\text { Tourism } & \text { Demonstration } \\
\text { Base } & \end{array}$ & National & National Tourism Bureau \\
\hline 2016 & $\begin{array}{l}\text { National } \quad \text { Agricultural } \\
\text { Tourism Demonstration Site }\end{array}$ & National & $\begin{array}{l}\text { Ministry of Agriculture, National } \\
\text { Tourism Administration }\end{array}$ \\
\hline 2017 & $\begin{array}{l}\text { China's top ten beautiful } \\
\text { terraced fields }\end{array}$ & National & Ministry of Agriculture \\
\hline 2017 & $\begin{array}{l}\text { Health-preserving } \\
\text { (Longji Town) }\end{array}$ & Provincial & $\begin{array}{l}\text { National Development and Reform } \\
\text { Commission, Ministry of Finance, } \\
\text { and Ministry of Housing and Urban- } \\
\text { Rural Development }\end{array}$ \\
\hline
\end{tabular}




\begin{tabular}{llll}
\hline $\begin{array}{l}\text { YEA } \\
\mathbf{R}\end{array}$ & NAME & LEVEL & AWARDING BODY \\
\hline 2017 & $\begin{array}{l}\text { Traditional Chinese Village } \\
\text { (Xiaozhai) }\end{array}$ & National & $\begin{array}{l}\text { Ministry of Housing and Urban-Rural } \\
\text { Development, with Ministry of } \\
\text { Tourism }\end{array}$ \\
2018 & $\begin{array}{l}\text { Global } \\
\text { Agricultural } \\
\text { Heritage } \\
\text { Longsheng Longji Terraced }\end{array}$ & $\begin{array}{r}\text { Important } \\
\text { Cultural }\end{array}$ & $\begin{array}{l}\text { Internation al } \\
\text { Food and Agriculture Organization } \\
\text { (FAO) }\end{array}$ \\
2019 & $\begin{array}{l}\text { Field System) } \\
\text { National Rural Tourism Key } \\
\text { Village }\end{array}$ & National \\
\hline \hline
\end{tabular}

Source: Luo (2018)

\section{Development Stages of Rural Tourism}

Data for this section came from secondary sources and personal interviews in the community. The origin of RT in the Dazhai community can be traced back to more than 40 years ago. As one of the poorest villages, the Dazhai community developed tourism through the government's strategic guidance. It has undergone six stages of development starting from (1) a spontaneous development period, (2) period of exploration and development, (3) period of steady growth, (4) period of improvement and adjustment, (5) maturity, and (6) stability. The features of each stage are presented in Table 5.

North (1994) says that "inductive institutional changes must be caused by a certain profit opportunity that cannot be obtained under the original institutional arrangement." Villagers wonder about and decide to engage in agricultural farming and activities other than agricultural farming. Starting as part-time jobs, new market institutions and transaction relationships following traditional values, ethics, morals, and habits emerged from interactions with tourists.

\section{Table 3. Stages of tourism development in the Longji Scenic Area}

\begin{tabular}{|c|c|}
\hline STAGES & FEATURES \\
\hline $\begin{array}{l}\text { Spontaneous } \\
\text { development period } \\
(1975-1991)\end{array}$ & $\begin{array}{l}\text { - Mainly for sight-viewing from the beautiful terraced fields in the early } \\
\text { days, visitors including journalists, photographers, and painters; } \\
\text { - The villagers were enthusiastic about receiving visitors and did not } \\
\text { take profit; visitors paid with tips; } \\
\text { - Visitors publish photos of the views from terraced fields, and early } \\
\text { publicity was given by word-of-mouth communication. }\end{array}$ \\
\hline $\begin{array}{l}\text { Exploring period } \\
(1992-1998)\end{array}$ & $\begin{array}{l}\text { - The number of tourists has gradually increased, and most tourists } \\
\text { prefer to spend one day on the tour; } \\
\text { - Ethnic tourism products and handicrafts were developed for } \\
\text { souvenirs; } \\
\text { - Marketing promotion was through television and magazines; } \\
\text { - The tourism activities mainly happened on foot, with infrastructure }\end{array}$ \\
\hline
\end{tabular}




\begin{tabular}{|c|c|}
\hline STAGES & FEATURES \\
\hline & $\begin{array}{l}\text { not complete and transportation inconvenient; } \\
\text { - The government starts to pays attention to it, and residents show } \\
\text { active participation in tourism activities. }\end{array}$ \\
\hline $\begin{array}{l}\text { Stable growth period } \\
(1999-2003)\end{array}$ & $\begin{array}{l}\text { - Tourists reception facilities were continuously improved; } \\
\text { - The target group of tourists started to be diversified, with individual } \\
\text { tourists and group customers from travel agencies appearing; } \\
\text { - The development subject started to be clear, with management } \\
\text { being orderly. }\end{array}$ \\
\hline $\begin{array}{l}\text { Improving and } \\
\text { adjusting period } \\
\text { (2004-2008) }\end{array}$ & $\begin{array}{l}\text { - Focus on marketing promotion; } \\
\text { - National cultural tourism products and cultural brands were } \\
\text { specifically built; } \\
\text { - Tourists increased rapidly. }\end{array}$ \\
\hline $\begin{array}{l}\text { Mature and stable } \\
\text { period } \\
(2009-2017)\end{array}$ & $\begin{array}{l}\text { - Improvements were gradually accomplished with internal facilities } \\
\text { in Longji Terrace Scenic Area; } \\
\text { - With more villages participated in tourism activities, a pattern of } \\
\text { "one village and one special feature" begun to form; } \\
\text { - Villagers' service awareness improved, with increasingly mature } \\
\text { operation and management. }\end{array}$ \\
\hline $\begin{array}{l}\text { Quality tourism period } \\
\text { 2018-present) }\end{array}$ & $\begin{array}{l}\text { - Enter a new era of "quality tourism" development; } \\
\text { - Facing new requirements for the transformation and upgrading of } \\
\text { tourism products. }\end{array}$ \\
\hline
\end{tabular}

Sources: Luo (2018); Personal interviews

At the early stage, villagers were organized to collect entrance tickets. Reporters, photography enthusiasts, and painters were the main visitors for sight-viewing, and villagers did not take payment; they just enthusiastically received visitors who may give voluntary tips. These tourists then published photographs of and articles about terraced fields, which served as early publicity. From the mid-1970s to the early 1980s, the Longji Terraces attracted tourists because of their unique terraced landscape, unique farming culture, and beautiful natural ecological scenery. The tourists' visits stimulated the villagers' awareness of a commodity economy, and some visionary villagers then started tourism business activities focusing on restaurants and hotels.

In 1975, the beauty of the Longji terraces was revealed for the first time when a reporter came to Longji Ping'an Village to take photos. In 1978, the terraces were photographed by Hong Kong tourists guided by the staff of the Longsheng County Party Committee. These photos were exhibited in foreign countries, and by then, the Longji Terraces were known worldwide.

Under the framework of the government-led model, the government has acted as a "decision-maker," "guide," "coordinator," and "economic man" in the development of rural tourism communities (RTCs). In 1988, the Longji Scenic Area was established as a provincial-level scenic spot, which was the first step in the development of local tourism 
industrialization. This marked a time when most RTCs around the scenic area entered a mandatory institutional change (Table 6). Most of them were developed under the government's control because it can efficiently and rapidly construct tourism infrastructure and reduce the cost of institutional changes.

In 1990, the sand road from He'ping Township to Longji Jinzhu village was prepared to receive tourists. $\mathrm{Wu}$, the then deputy general manager of Longsheng County Tourism Corporation (LCTC) and general manager of Longsheng Hot Spring Hotel, compiled the Longsheng National Customs Tourism Plan in 1992 and proposed the concept of tourism poverty alleviation. In 1992, the LCTC operated the Longji Scenic Area on a trial basis. The ticket price was set at CNY 2 per person, and the number of tourists gradually increased. At the end of 1992, the Longsheng County Government formally began to implement propoverty tourism. Tourism, thus, became an important means of poverty alleviation. This was also included in the national economic and social development plan for Longsheng County. In 1993, the LCTC used the Jinzhu village to build a folk song and dance performances scene. In 1994, through the reporting of photographers and television stations, the Longji terraces' beauty attracted great attention from photographers at home and abroad. The LCTC began to intervene in this scenic spot's tourism activities, and Longji Tourism was officially launched.

After 1995, the development of the Ping'an Terraced Field Viewing Area in Longji Scenic Area focused on the Hongyao culture, such as carrying out a performance showcasing the long hair of Hongyao women and selling special tourist crafts. In 1996, Longsheng County developed a strategy for establishing a tourism county and increased investment and support for the Longji Scenic Area. In 1997, the county government used work-for-work project funds to build safe highways, which were opened to traffic at the end of 1998.

Table 4. Changes in the development models of rural tourism in Dazhai

\begin{tabular}{|c|c|c|c|}
\hline CONTEXT & $\begin{array}{l}\text { FIRST STAGE } \\
(1975-1987)\end{array}$ & $\begin{array}{l}\text { SECOND STAGE } \\
(1988-1998)\end{array}$ & $\begin{array}{l}\text { THIRD STAGE } \\
\text { (1999-PRESENT) }\end{array}$ \\
\hline Demands & Demand starts to emerge & Rapid growth in demand & Demand boom \\
\hline Subjects & Residents & Local government & $\begin{array}{l}\text { Tourism enterprise; Local } \\
\text { government; residents }\end{array}$ \\
\hline Drivers & Economic benefits & $\begin{array}{l}\text { Political and Economic } \\
\text { benefits }\end{array}$ & $\begin{array}{l}\text { Political and economic } \\
\text { benefits for all }\end{array}$ \\
\hline Activities & Market exploration & $\begin{array}{l}\text { Management } \\
\text { improvement }\end{array}$ & $\begin{array}{l}\text { Distribution of Property } \\
\text { Rights }\end{array}$ \\
\hline Means & $\begin{array}{l}\text { Informal institutional } \\
\text { arrangements ("bottom- } \\
\text { up" inducement) }\end{array}$ & $\begin{array}{l}\text { Formal institutional } \\
\text { arrangements } \\
\text { (“Top-down” mandatory) }\end{array}$ & $\begin{array}{lr}\text { Informal and } & \text { formal } \\
\text { institutional } & \\
\text { arrangements } & \text { are } \\
\text { compatible } & \text { (a } \\
\text { combination } & \text { of }\end{array}$ \\
\hline
\end{tabular}




\begin{tabular}{|c|c|c|c|}
\hline & & & $\begin{array}{l}\text { inducement } \\
\text { coercion). }\end{array}$ \\
\hline Results & $\begin{array}{l}\text { The Dazhai community } \\
\text { has initially formed a } \\
\text { tourism } \quad \text { micro- } \\
\text { management } \\
\text { mechanism. Problems } \\
\text { such as externalities of } \\
\text { the tourism industry have } \\
\text { also arisen. }\end{array}$ & $\begin{array}{l}\text { The government } \\
\text { strengthens industrial } \\
\text { construction promotion in } \\
\text { tourist destinations and } \\
\text { surrounding } \\
\text { communities, but there is } \\
\text { a game between the } \\
\text { government and other } \\
\text { stakeholders. }\end{array}$ & $\begin{array}{l}\text { Government } \\
\text { decentralization, } \\
\text { enterprise activation, and } \\
\text { residents' participation, } \\
\text { but due to the imbalance } \\
\text { of interests, a new round } \\
\text { of games has emerged. }\end{array}$ \\
\hline
\end{tabular}

Source: Adopted from Wu \& Luo (2020), Luo (2018), and compiled by the author

The path of institutional change is based on the earlier and more mature Longji scenery of the tourism industry. The district's core location is represented by the Dazhai community, which reflects the institutional trend of most RTCs. The current management model of Dazhai is the result of a long period of exploration and development. In 2000, the Guilin Tourism Development Master Plan (2001-2020) was compiled by the Tourism Development and Planning Research Center of Sun Yat-sen University. This plan first defined the main stakeholders in the development of Guilin tourism (i.e., the government, commercial departments, tourists, residents, scenic developers, etc.) and analyzed in detail the mutual constraints and interactions among the main stakeholders. By integrating the actual situation of Guilin, the development strategy for Guilin tourism was proposed.

The complexity of the interaction of various factors determines the uncertainty of the development direction of the RTC, the variability of the development trajectory, and the dynamics of stakeholder relationships. In this regard, its management models could be divided into three stages, which are discussed in the following sections.

\section{Local Institutions in the Development of Rural Tourism in Dazhai}

Longji scenic area is the first batch of provincial-level scenic spots named by the People's Government of Guangxi province in 1988 (the area was in a state of pending development until 1993). In 1994, Longsheng County Tourism Company (LCTC) began to intervene in the tourism work of the scenic area. In September 2003, Dazhai began to attract tourists and entered a new era of comprehensive development and overall opening. Since the official launch of the tourism, it has strictly controlled the quality and followed a standardized development path. During the construction of the scenic area, it actively referred to the construction and protection requirements of various evaluation standards, and won numerous honorary titles. The main management units include the Bureau of Investment Promotion(BIP), the Bureau of Tourism, Culture and Sports(BTCS), the Bureau of Agriculture(BA), the Office of Longji Terrace Scenic Spot Area(OLJTSSA), the Office of Target Poverty Alleviation(OTPA), the Bureau of Ecology and Environment Protection(BEEP), and the universities and social organizations, which formulate a related systems to promote the coordination of the development and protection of the scenic spot, 
and ultimately promote the development of tourism.

Guilin Tourism Plan(2001-2020) was laid out by Guilin government documents in the Tenth-five-year Plan (2000-2005) in 1999, and in 2002 Dazhai was developed by the Longsheng County, as protected areas for nature, culture and heritage, which was later honored the Longji Terraces Scenic Spots Area(LJTSS) by the central government. Related to this, the Longsheng Tourism Plan in the Tenth-Five-year Plan: the Longji Terrace Scenic Spots Area Conservation Development and Management Plan (LJTSSACDMP) (2004-2020), pointed out that the Terrace Area principles were that management would be applied at minimal but effective levels within the scenic spots, and that conservation of the natural environment, nature communities and scenic resources would receive priority attention.

In 2000, the central government drafted the DWCS to establish guidelines and a framework for the growth and development of tourism in the country. It promotes tourism as one of the key economic sectors, contributing effectively to GDP growth and encouraging private sector involvement in Western China Area and to minus the gaps between the Eastern and Western Area. The mission is to use tourism as the main contributor to the growth and well-being of the people in rural areas of China, through the development of a dynamic, competitive and customer-driven industry that will ensure that the rich cultural heritage and natural environment and beauty of China are conserved, and that local people are the prime beneficiaries of tourism development. The Chinese Tourism Master Plan (2006) states that the mission of RT is to: (1) ensure public awareness of the values of the resources; (2) facilitate community and public access to the site and provide appropriate services including opportunities for interpretation, education and research; (3)ensure effective integration of the protected area system in the social, economic and environment spheres, and (4) promote sustainable lifestyles and land use of communities who live adjacent to the site. Based on this, the Chinese government should provide RT with emphasis on public awareness of social, environmental and economic benefits of tourism and improving the lives of local people.

Before 2002, Dazhai was notoriously poor with extremely backward development, almost no communication, inconvenient transportation, no source of income, and close to meager agricultural income. Unitl 2003, Guilin Longji Tourism Development Company (LJTDC) and Dazhai jointly developed the terraces field area for rural tourism, and great changes have been taken in the community.

Local government has a structure of tourism institutions and its management. The section below explains the tourism institutions as actors in Dazhai tourism management. The State Council (SC) is the top leader of all events and affairs from the national level. Each level of the institutions is at first under the its CPC council's leadership. The Ministry of Culture and Tourism (MCT) manages tourism under the leadership of the SC and gives outline documents in Guangxi province. MCT formulates tourism policies, strategies and acts of the provincial levels, like Guangxi province. And the provincial government or Guangxi province government gives related tourism policies and strategies, as well as acts and plans for the municipal cities, like Guilin City. Then Guilin city gives the detailed plan for tourism development for the prefectural levels, like Longsheng County. The Guilin 
Tourism Master Plan (2001-2020) (GTMP:2001-2020) states that the plan reaches around 20 years and is divided into three stages trying to make Guilin an international tourism city. For the objectives of building a pilot tourism county, the Longsheng prefectural government makes detailed plan for the development of RT in the administrative area and the township tourism development offices assist the upper levels for the implementation. And the community affairs council (CAC) as well as the CPC branch council take detailed and specific measures for the development and management in the communities. Figure 1 shows the hierarchy of the institutions at each level:

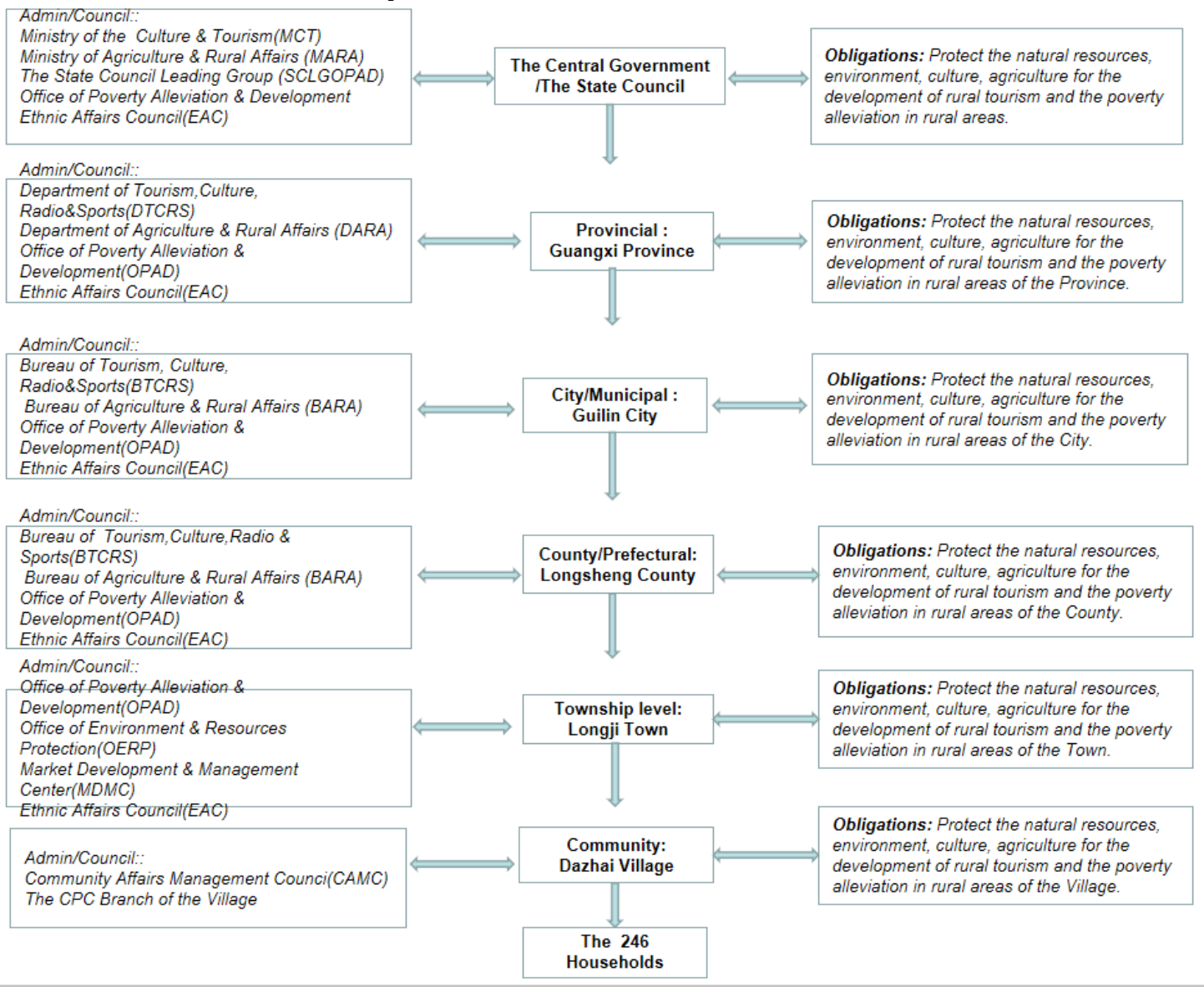

Figure 2. Related institutions on tourism development (Local government units).

Source: various sources

The LJTDC is a private company, firstly set to develop the tourism in Dazhai Village, and to help with the management of tourism in Longji Terrace Scenic Spots Area. Before 2002, the company was established in terms of the Tourism Act, and signed the contract with the Longsheng government for the development. The contract pointed out that the company gets profits from the management of the terraces scenic spots and the operations. The villages included or around the scenic spots could benefit from only $15 \%$ of the tourism ticket fees in 2003, the first time for the contract, and modified in 2007 to raise the benefits for the communities, and once again modified in 2013 to clarify a higher proportion for the profits to the community and the villagers. And the surrounding communities and the 
villagers can also get shares from it, like profit dividends, employment, as well as the opportunities for business shops.

Local authorities form part of the actors in tourism management. Local authorities are required to plan for tourism development and activities without additional resources (Lekaota,2014). The literature points out that in most developed countries municipalities and other local or district bodies play a very important role in the promotion and marketing of local tourism (Page \& Thorn, 1997).

Associations or the non-government organizations (NGOs) play a role of bridge for the development of tourism and express policy documents to the industry and LGUs. They can help with the management of tourism to overcome obstacles in investment and business start-up, together with competitiveness. In Longsheng county the following sectorial associations have been established and are to some extent active in the pursuit of business facilitation for their members: - associations for transport operators serve tourist needs, hotels, tour operators, museums and heritage destinations; lodges; arts and crafts suppliers; performing arts operators; B\&B's; and caterers (Lekaota,2014). The Longji Scenic Spots Management Association for Tourism was established by the company for effective management for the tourism areas, representing its interests as well as being an effective mouthpiece for the company. There are a series of related associations set for the development of tourism, like China Tourism Association (CTA), Guilin Tour Guide Association (GLTGA), Guilin Environmental Protection Association (GLEPA).

Private sectors play critical role in the development and promotion of tourism. Because private enterprises create roles in employment creation, promoting tourism and investment in tourism. In currently, in Longsheng county most of the business are small business shops, the villagers can save themselves by operating their own shops by hotels, caterings, as well as the transportation operators. While, the business enterprises like LJTDC and other Travel Agencies and hotels cooperatives play an important role in the facilitation of tourism development. And most of the workers are employed from the community, meanwhile they also get some managers from the urban cities to train skills and professions. Thus we can see the role of private enterprise could be of particular significance in the demonstration of innovative practices and the encouragement of new types of tourism business activities(Lekaota,2014).

Expertise is also important to the development of the tourism, since the experts are those from industry or academicians or higher education institutes with deep experience and professions in it. They offer suggestions from the very professional perceptions and know more about how to make full use of the natural and cultural resources for the development of tourism. And thus make tourism development sustainable. Dazhai, itself, is of different natural and cultural resources, like the terraces, and the minorities' cultures as well as the costumes. Thus, the expertise can be from history science, landscape, and ethnics, as well as tourism planning. And many of them come from the universities in Guilin, like Guilin University of Technology, Guangxi Normal University, and Guilin Tourism University, also there has been many experts from other universities like Zhongshan University in Guangzhou city and China Social Science Institute, as well as China Tourism Study Institute. There can be different forums for the development of tourism in Guilin and the experts give their ideas professionally. 
The community is of great importance in the procedures of tourism development. They are the original residents in the community and know more about the culture, history and the changes as well as the other traditions there. They know better about the natural resources and the characteristics of the village and they are the only ones master the ethnic performance, crafts, and architectures there. On the other hand, there may exist some old norms and rules as well as some old authorities, in China, we have some miracle disciplines or we call it "Fengshui", you may know very little about it but you have to obey it, since this has already been there deep-rooted with long history. Aside from this, the developers have to consider the existing bully groups in the village, and they may raise some bad actions towards the operation of the tourism development. Therefore, we can see the important role in the community in the development of tourism industry in the rural areas. And actually, the tourism development should be, in the end, make benefits for the communities and to help poverty reductions, but not only for the benefits of the few elites. The following figure shows the institutions of rural tourism in Dazhai.

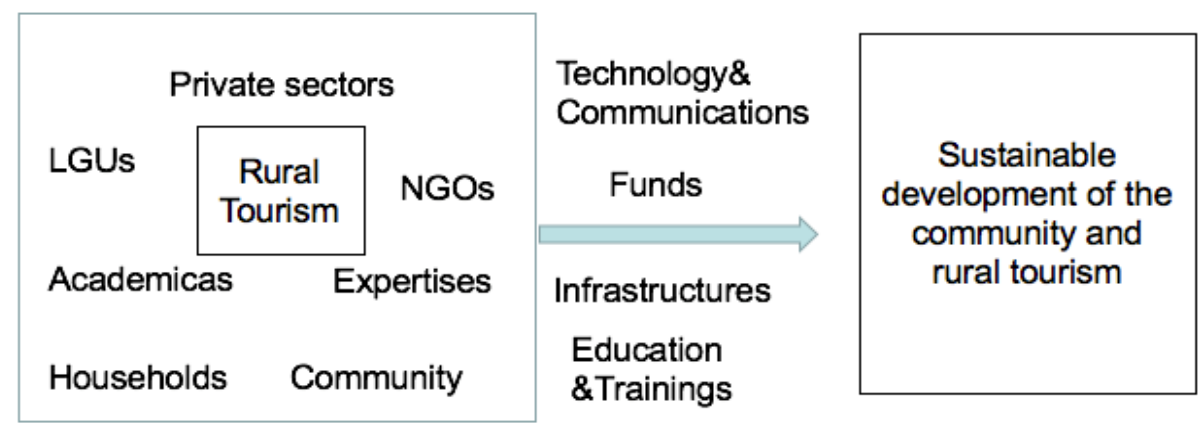

Figure 3. The institutions of rural tourism in Dazhai.

Source: Atienza (2011); various sources

Longsheng County currently implements a three-level tourism administration management system consisting of Longsheng County Tourism Industry Leading Group (LCTILG), Longsheng County Tourism Management Committee (LCTMC), the BTCS, and Longsheng County Tourism Economic Development Service Center (LCTEDSC) (Figure 3). 


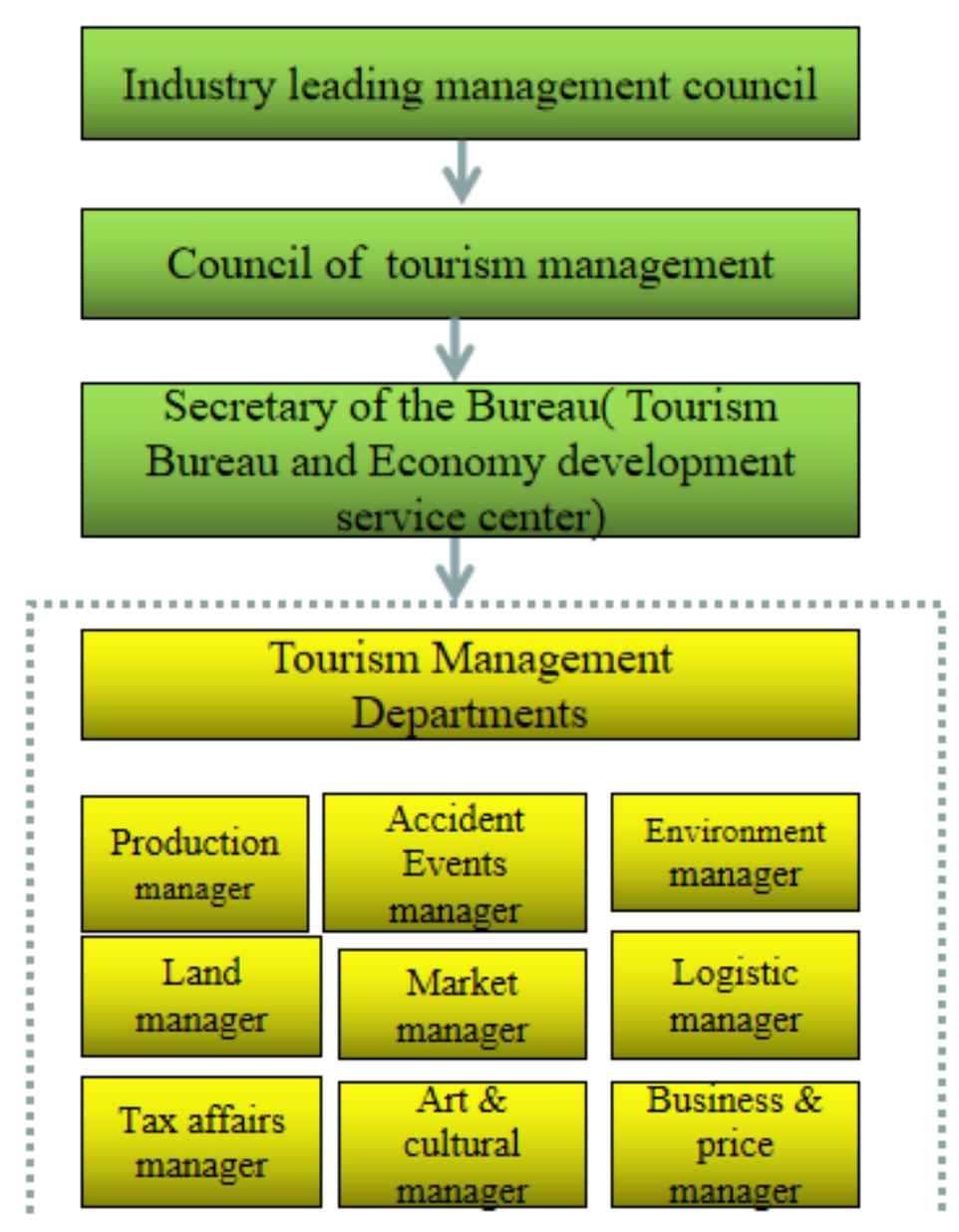

Figure 4. Tourism administration management departments in Dazhai community.

Source: Personal interviews.

The LCTILG is the decision-making body for the development of the tourism industry. The secretary of the county party committee personally serves as the group leader, and the deputy secretary of the county party committee and the secretary of the discipline inspection committee serve as the executive deputy team leaders; the LCTMC serves as the coordination agency for the development of the tourism industry. The Deputy Secretary of the County Party Committee (DSCPC) and the Secretary of the Disciplinary Inspection Committee (SDIC) serve as the director of the Tourism Management Committee (TMC). The members are composed of heads of tourism-related functional departments such as urban construction, environmental protection, industry and commerce, taxation, land management, and prices, forming a linkage mechanism for all departments in the county to jointly manage the tourism industry. Under the unified leadership of the LCTILG and the specific guidance of the TMC, the BTCS is mainly responsible for tourism policy formulation, planning, tourism resource development and tourism industry management; LCTEDSC specializes in Longsheng promotion of tourism image and marketing of tourism 
products.

\section{Formal and Informal Institutions in Dazhai}

Institutions are divided into formal and informal institutions. A formal institutions refers to a code of conduct that is determined in a clear form, and there is a corresponding organization to supervise the actors, and it is used to ensure the implementation of coercive force, such as various written laws, regulations, and policies, regulations, contracts, etc. Informal institutions refer to the behavioral norms accepted by people in an unconscious state, including values and ethics, customs and cultural habits, ideology, etc. This article mainly analyzes the formal institutions at the national level and the formal institutions at the local level that have significant constraints and influences on the tourism development of the Dazhai Community in the case, as well as informal institutions such as folklore norms.

\section{Formal Institutions}

All policies, strategies and informal institutions, generally are issued and macroregulated by the central government. Governments from each level will adjust and issue the specific policies for the certain regions according to the national policies. In this research, formal institutions are all policies or institutions related to tourism and "three rural issues", they are basic-level mass autonomy institutions, land management institutions, national leave policies and rural tourism policies and series of policies mentioned in chapter I. When the influence of rural authority or accidental events is large enough, they will be shown to rural residents in the eyes of village managers (Zhang, 1999; Wang, 2018). The central government plays a prominent role in formulating and implementing processes from top to bottom, policies are implemented layer by layer in accordance with some given procedures. The embedding of national policies in rural tourism destinations is achieved under the interaction and restriction of multiple departments.

\section{Land management institutions}

Since 1950s, China has issued a series of standardized land management institutions and regulations. The reform of land ownership and changes in rural land policies have profoundly affected rural development and farmers' incomes. The "Land Administration Law of the People's Republic of China", "Regulations on the Acquisition and Compensation of Houses on State-owned Land" and other laws and regulations are important basis to lease rural land to tourism development. For example, in 2014, China put forward the document "Several Opinions on Promoting the Reform and Development of the Tourism Industry", which specifically lease the land use policies to promote land use rights and joint ventures through partnerships collective economic organizations with individuals. Constructions for business use have to involve all legal procedures for land use. The promulgation of this policy provides a basis for land use in Dazhai.

\section{Basic-level mass autonomy institutions}


Basic-level mass autonomy institutions are grassroots self-regulated institutions, which are based on China's constitutions and laws, meaning "everyone is the host of the nation". For example, the community affairs council which is formed to represents the local residents for self-management, self-education, self-service, and self-supervision. Members are elected by the residents (village). On the basis of this institutions, Dazhai community has also carried out various autonomous regulations in accordance with the actual situation.

\section{$\underline{\text { Holiday policies and institutions }}$}

Holidays such as the Spring Festival, the National Day, May Day, Middle-autumn Day, Qingming Festival, Mid-Autumn Festival and Dragon Boat Festival have greatly promote the development of tourism, these are all important days for the people. The State Council of China has promulgated series of holidays policies for the whole nation. In 2007, the new "National Holidays and Anniversary Holidays", and also promulgated the "Regulations on Paid Annual Leave for Employees" forming a new leave institution, and has led to holiday economy. At the same time, the convenient access to high speed train and free highway access was opened on legal holidays, which led to the rapid development of short-distance tourism.

\section{Policy support related to rural tourism}

As has mentioned in Chapter I, since the reform and opening up, the central government has continuously focused on the "three rural issues" for decades and regarded it as important political tasks for the nation. Local governments, such as Guilin Municipal Government as well as Longsheng prefectural government have issued related policies and strategies for action plans to ground levels since 2003,such as the Strategy of Rural Revitalization. Investments and special funds have been given in basic implementation, public services and supporting facilities in Dazhai Community. All has created a favorable environment and a good atmosphere for Dazhai Community's innovation experiment, and also clarified the direction of Dazhai.

\section{Community management institutions}

Dazhai rural tourism management forms are divided into four parts: specifically, there are community affairs council, industry associations, tourism companies, and Longji Scenic Area Management Association. Among these four tiers, the industry associations belong to the villagers' self-organization group; the community affairs council is the highest decision-making body of the community, and needs to take into account the responsibilities of local development. It has the right to make plans and specific implementation rights for the village; The main responsibility of Longji Tourism Development Company is to manage and operate the scenic tourism market.

On the other hand, Dazhai Community is located at the core of the Longji Scenic Area. The terraced fields owns the core resource for the development of local rural tourism. In 2003, it formally signed an agreement with Guilin Longji Tourism Development Company to distribute profit according to the agreement. $20 \%$ is used for the maintenance of terraces, and the rest is distributed to the villagers according to the number of acres. To 
a certain extent, the residents of Dazhai community are "shareholders" and all enjoy dividend income.

\section{Informal Institutions}

Informal institutions, which can also be understood as informal restraint, refers to a code of conduct that is accepted by people in an unconscious state. This code of conduct is generally formed spontaneously after a long time of accumulation, including values, ethics, and customs, cultural habits, ideology, etc. It mainly analyzes the informal systems that have significant constraints and influences on the evolution of the Dazhai Community tourism development in the case, mainly including the power of the squire, the Zhai lao institutions (the elder authorities), Feng shui, etiquette and customs, collectivist values, the signing of integrity agreements by the operators and the independent establishment of civil organizations, etc.

\section{Written and unwritten rules and regulations in the community}

Village rules and regulations, are usually established to manage public utilities and coordinate the relationship between residents. It is the customary law of the village society, and some of them are written in order to be followed and implemented, but some are unwritten. It has binding force on villagers and ethnic groups (Zheng, 2016). In addition to the village rules and regulations, there also exists the moral principles and precautions of unifying the thoughts and behaviors of the members. In particular, the code of conduct should be standardized to tell the people what should be done or not (Zheng, 2016). In Dazhai the written regulation is the "Community regulations in Dazhai" which can be seen in the appendix.

Some written village rules and regulations have been formed and distributed to all households. Village rules and regulations are generally binding only on the villagers in the village. However, with the increase of external tenants, the villagers generally require the external tenants to abide by the village rules and write them into the lease contract. However, due to the lack of legal effect, the binding force of village rules and regulations has gradually weakened with the development of the times and the changes of ideology, institutional elites actively draft and implement village rules and regulations. They simplify the original village rules and regulations and update the contents with the development of the times. The main purpose is to standardize the villagers' behavior and the overall image.

The unwritten rules and regulations include preemption doctrine, lottery distribution institutions, shop rental institutions that affect the participation of villages in tourism development are mainly reflected in the distribution system of property or income. For example, in the early stage, villagers spontaneously carried out the mobile selling, which followed the conventional principle of preemption to allocate the selling positions. With the development of tourism, fixed stalls were built for regulated business. Then the traditional lottery distribution system effectively solved the contradictions and disputes among villagers, the villagers would consciously abide by it.

And the allocation of the right to use collective shops in communities is carried out 
by means of bidding and leasing. The ownership of collective shops is owned by the collective. Selling is prohibited and the right to use is allocated by means of competitive bidding and leasing. Only the villagers of the village can participate in the bidding, and the villagers can freely transfer and lease after successful bidding with a lower rental price of shops. However, due to the poor efficiency of shops and the villagers' enthusiasm for renting shops, they allowed external tenants to settle in and the rental income of shops is owned by the collective.

\section{Rural authorities}

In China's traditional rural areas, rural authority often refers to people who have a certain degree of influence in the area. In Dazhai, it is mainly the community head and the community party branch secretary who play a big role in community affairs. The community head is such a rare community leader with foresight, wisdom, high sense of responsibility and eloquence in ordinary rural areas, who is the backbone and accumulated considerable political and social resources in the process of serving as a grass-roots leadership.

The researcher interviewed the community manager who can be thought of as a local authority. The community manager can also be taken as elite, since he has been the secretary of the community council since 2005, which has been around for 15 years. He showed a strong sense of being independent with good knowledge and qualified as entrepreneur, and willing to take risks (Zheng, 2016). And he was with the first group to participate into tourism activities; hence he has a great sense of responsibility and ownership of the community affairs. However, during his days in his current position, he has to face different difficulties, since not everyone will stand by his side. To gain more prestige and reputation, sometimes he has to offend the others for the benefit of the majority. Eventually, he won more respects from those who had doubted him before.

On the other hand, even if the villagers have criticized the centralized management mode, they have formed psychological dependence on the patriarchal system to a certain extent due to their dependence on authority for many years. They hope that one person will always be responsible for important decisions or transformative actions in the community. To some extent, this can explain the reason why the head of the community has been reelected for more than ten years.

\section{$\underline{\text { Clans }}$}

Most of the villages in Longsheng County are Zhuang and Yao minority people live there. Dazhai is a typical minority community. It has a long history of settlement in gathering together. Most of the villagers are the descendants of the same ancestor, and they have close or distant blood relationship with each other. Dazhai residents are mainly based on the surname Pan. The family size and economic strength are very prominent and the power is relatively strong, and a few other surnames are all for recruitment.

In the past 20 years, the community head are usually the institutions elite with more economic and social resources, they are the authoritative figures in the village. Thus it has 
changed very little, the villagers believe in the authoritative leadership and the blood ties, the cohesion in the village is relatively strong. For the decision-making of major affairs in the village, villagers listen to the collective arrangement, and some vulnerable groups choose to bear their breath even if they hold different opinions. Sometimes, village leaders often try to avoid tearing apart the relatives' feelings and avoiding conflicts and disputes. And this seems difficult to change, since the clan forces are deeply rooted. For example, Surname Pan has the largest number of people in the village, accounting for $70 \%$ and $80 \%$ of them are from the same clan institutional family. Everyone is a relative. They would just obey but not oppose. Sometimes, the community council will encounter some difficulties, such as unwilling to cooperate with the extension of rice harvest for more tourists. The manager prefers to make things simpler, since it's more difficult when two get different viewpoints but they are reasonable. This couldn't always be seen as democracy, it has to be dealt on sacrificing another's benefit, which is done for authority.

\section{Zhai Lao (called "elder headman")}

Zhai Lao (called "headman") is the natural leader of the village. Generally, he is a person who is very old, or although he is a young man, but is fair, enthusiastic about local public welfare, and has certain prestige among the masses. When promoted as the leader, he must actively organize activities and seriously implement the village regulations. Most Zhai Lao are produced naturally, and a few are elected by various Fang ethnic groups. They exist in ethnic minority villages and tribes such as Dong or Zhuang. When coming to some important matters related to the village, it plays a leading role in the formulation, implementation and recognition of the village law, resolve various disputes in the village according to traditional customary laws, mobilize or organize the people in the village to establish various public welfare undertakings, etc. Externally, as the representative of the village, he handles external affairs and economic negotiations, organizes and directs the whole village to resist outside aggression.

\section{$\underline{\text { Traditional Ideas and Values }}$}

In the process of participating in tourism development, villagers are influenced by traditional ideas and values in many aspects, which are reflected in specific decisionmaking actions. For example, fengshui is a profound technique with a long history of the Chinese nation, that is, a method of spot-checking geography. It is a philosophy that studies the environment and the laws of the universe. The core idea is the harmony between man and nature. Early fengshui was mainly related to palaces and residences. The methods and principles of site selection, orientation and construction of villages and cemeteries are a metaphysics for choosing suitable places. The ancient Chinese people practiced fengshui for two main reasons: one was good for agricultural production, and the other was good for living. In short, the scientific nature of fengshui is reflected in the fact that good fengshui is beneficial to agricultural production and human habitation. Whether in the process of building new villages or demolishing old villages, the villagers take fengshui into consideration in decision-making actions.

In China, the system of emphasizing agriculture and restraining commerce has been 
carried out in all dynasties. The thought of "attaching importance to agriculture and neglecting commerce" has accumulated into the mainstream ideology of people in the longterm evolution of agricultural society (Zheng,2016). On the other hand, they are influenced deeply by collective economy, villagers work together to strive for more benefits for the village collective, which requires the unity of collective values.

\section{Analysis of Institutions on RT in Dazhai}

From the perspective of the relationship and game between the national and local levels, no matter what development path a village takes, the country's institutional constraints on the village are inseparable. This constraint is reflected in the formal system of the state to regulate rural affairs to ensure the rural areas order and management. Among them, the land management and the grassroots self-government institutions are closely related to the villagers of Dazhai. Since the promulgation of the institutions, the villagers followed the relevant national regulations to handle rural affairs for many years before the development of tourism in Dazhai. The grassroots self-government institution is embedded in rural management affairs, while the land management institution is embedded in rural land use and construction affairs. In addition to the embedding of the national institutions related to rural affairs, the national vacation system provides guarantees for the leisure time of urban residents, and at the same time provides support for the development of tourism in rural areas. Although the national vacation system appears to be embedded outside the countryside, it actually, however, has an important influence on the development of rural tourism.

A series of policies promulgated by the state to promote the development of rural tourism have directly promoted the development of rural tourism in Dazhai Community. It has been developing on the road of rural tourism since 2003, and the national policy orientation has been implemented and brought into play in local villages. However, the formal institutions related to tourism is embedded in the rural development in a recessive state. Only when the influence of the rural authority or accidental event is large enough, will it enter the rural residents or rural managers in a dominant state. To sum up, the formal national institutions limit the scope and boundaries of the rural actors' choice and is embedded in the rural management affairs and the internal interactions of various institutions.

\section{Interactions among RT Institutions in Longji}

As mentioned above, the tourism stakeholder groups include local governments, tourism enterprises, rural tourism communities, residents and tourists, etc. Based on the goal of benefit sharing, each stakeholder has a different role and an irreplaceable key role. Terraced landscape in Longji Scenic Area, is mainly concentrated in Dazhai, but also involves other villages, such as Ping'an, thus the tourism resources of this area belong to different village collectives and villagers, which should seek a reasonable way to resolve 
the interest conflicts of stakeholders, and implementing the relationship and division of labor between stakeholders can improve the tourism service quality in the scenic spot and realize tourism resources full used. Games among various stakeholders in the scenic area is mainly reflected in the following aspects:

\section{Interactions between local government departments and tourism companies}

Local government management departments and tourism companies influence each other. Within the limits set by the government, relevant tourism companies will adopt various countermeasures to maximize economic benefits.However, government departments have the right to coordinate and allocate resources of public attributes, and they often use various means to influence and intervene in enterprises in order to make the game results beneficial to them. The specific game mode of the two parties can be summarized as:

\section{Table 4. Interactions s between rural management departments and rural tourism enterprises}

\begin{tabular}{ll}
\hline \hline Institution & Interaction Mode \\
\hline Local governments & $\begin{array}{l}\text { Formulate investment promotion policies; reach business agreements } \\
\text { with tourism companies; supervise tourism companies; resolve conflicts } \\
\text { between tourism companies and other stakeholders }\end{array}$ \\
Tourism enterprise & $\begin{array}{l}\text { Reach an operating agreement with the rural management department; } \\
\text { pay the store rent and other management fees to the rural management } \\
\text { department in accordance with the agreement }\end{array}$ \\
\hline \hline
\end{tabular}

The government played an important role in the development of Longji Scenic Area. Cultural festivals have been organized successively, and the national debt fund has been obtained to build scenic highways, and overall planning has been carried out, which has greatly promoted the tourism development of Longji Scenic Area. Before 2007, Longsheng County Bureau of Tourism, Culture, Radio and Sports(BTCRS), was responsible for the supervision and management of Longji Scenic Area. The Office of Longji Scenic Area Administration(OLJSAA) was established in August 2007, and it is a parallel unit with Longsheng BTCRS that is responsible for the planning and publicity of the scenic area, and the Scenic Area Administration is responsible for the implementation and management of specific affairs. The establishment of the new agency strengthened the supervision and coordination role of government departments over scenic spots. However, the groups represented by the two are different, the interests are different from the starting point, the interests of the travel companies are related, and many contradictions are difficult to coordinate in the management, which makes the work more difficult. 


\section{Interactions between local government departments and villagers}

In the development of rural tourism, the local government often needs to requisition land from local community residents. This land requisition process also embodies the interest game process between the local government and community residents.In the process of land acquisition, the government often adopts coordination and coercion measures for the development of rural tourism, and community residents may adopt two attitudes of cooperation or resistance because they are worried that there will be no economic source or subsidies to meet the needs of life after land acquisition. The game relationship between the village management department and local villagers is shown in the table:

Table 5. Interactions between rural management departments and residents

\begin{tabular}{ll}
\hline INSTITUTION & INTERACTION MODE \\
\hline $\begin{array}{l}\text { Local } \\
\text { government }\end{array}$ & $\begin{array}{l}\text { Expropriate land from villagers for tourism development; formulate tourism } \\
\text { development plans and policies; implement management of rural residents' } \\
\text { operations and tourism-related behaviors; resolve conflicts between villagers } \\
\text { and other stakeholders }\end{array}$ \\
Residents & $\begin{array}{l}\text { Safeguard their interests in the process of land acquisition by the rural } \\
\text { management department; express opinions and provide suggestions for rural } \\
\text { development; participate in RT by providing tourists with relevant tourism } \\
\text { products. }\end{array}$
\end{tabular}

\section{Interactions between tourism enterprises and villagers}

Residents of rural tourism communities are often the main body of tourism development in the process of rural tourism development. They directly increase their income by operating family hotels, processing and selling characteristic handicrafts, participating in transportation operations, etc., and participate in scenic planning and decision-making to safeguard their own interests.

The purpose of tourism enterprises in tourism operation is undoubtedly to obtain the greatest economic benefits through the least investment. In fact, tourism companies and community residents each have resource advantages in tourism development. The cooperation and mutual benefit between the two are inevitable, but the distribution of benefits between the two is different. The specific game relationship is shown in the table: 
Table 6. Interactions between tourism enterprises and residents

\begin{tabular}{|c|c|}
\hline INSTITUTION & "INTERACTION MODE \\
\hline \multirow[t]{3}{*}{$\begin{array}{l}\text { Tourism } \\
\text { enterprises }\end{array}$} & $\begin{array}{l}\text { Obtain the right to operate tourism resources, invest in RT projects, and carry } \\
\text { out promotion and management. }\end{array}$ \\
\hline & $\begin{array}{l}\text { When tourism companies use collectively-owned or private tourism resources, } \\
\text { they need to pay compensation fees for the use of resources to rural residents } \\
\text { collectively or as individuals. }\end{array}$ \\
\hline & $\begin{array}{l}\text { The reputation of tourism companies will affect the entire community. The } \\
\text { reputation of tourist destinations, in turn, affects the income level of community } \\
\text { residents. }\end{array}$ \\
\hline \multirow[t]{2}{*}{ Residents } & $\begin{array}{l}\text { After investing in tourism enterprises, residents participate in the tourism } \\
\text { industry's operation by building family hotels, restaurants, and shops; } \\
\text { producing and selling handicrafts; providing tourists with tourist facilities and } \\
\text { products, and becoming competitors in the competitive tourism market. }\end{array}$ \\
\hline & $\begin{array}{l}\text { Attitudes towards tourists will affect the quality of tourists' travel experience } \\
\text { and, in turn, affect the income of tourism companies. }\end{array}$ \\
\hline
\end{tabular}

In 2003, Longsheng Tourism Corporation signed a tourism development contract with the villagers of Longji Scenic Area to formally carry out the enterprise operation of the management right of the scenic area. In 2005, Guilin Longji Hot Spring Tourism Company (LJHSTC) was divided into Guilin Longsheng Hot Spring Tourism Limited Compan (GLHSTC) and LJTDC, operating Longsheng Hot Spring Scenic Area and Longji Terrace Scenic Area respectively.

The conflict between the tourism developer of Longji Scenic Area and the local villagers is reflected in ticket revenue distribution. In 2003, the ticket price of Longji Scenic Area was CNY 30 per person, and in 2004 it rose to CNY 50 per person, which was collected by tourism companies. Villagers received 5\% of the income from the ticket revenues. With the increase in ticket cost, the villagers became increasingly dissatisfied with the annual income, and the conflict of interest among tourism companies intensified. After many consultations, a new income distribution plan has been implemented since 2005 . In 2007, the Dazhai community and the tourism company re-signed an agreement. The company would return 7\% of the ticket revenue to Dazhai every year. In 2009, Dazhai decided to focus on the number of terraced fields, considering the number of households and population. They also tapped the village collective reserve to consider formulating a dividend plan.

Of the collective economic income, $50 \%$ is allocated to farmers according to their land area, $20 \%$ is allocated based on the number of villagers, $20 \%$ is allocated according to their household registration, and the other $10 \%$ is reserved for public welfare undertakings and other purposes in the village. In 2012, these distribution ratios were adjusted to $70 \%, 12 \%, 12 \%$, and $6 \%$. In $2017,70 \%$ of the village' s dividends were used to subsidize farmers' farming, $12 \%$ were distributed according to the village' $\mathrm{s}$ 
population, $12 \%$ according to the number of households in the whole village, $3 \%$ for village welfare (including village infrastructure construction, public welfare, education, publicity, etc.), and the remaining $3 \%$ as the village' s collective income. On the one hand, the majority of the villagers use their own funds or take out loans to finance their business, but the source of tourists is generally monopolized by the tourism companies. Thus, this kind of competition is obviously at a disadvantage for the self-employed villagers.

\section{Interactions among Villagers}

Public resources and the competition for tourists have produced unfair competition and violated the right to use property, which is the main manifestation of the conflict between villagers. First is the conflict between villagers who are engaged in RT operations and those who do not. Excessive use of public goods for tourism operations has caused environmental pollution and resource degradation. Residents who do not participate in RT want to maintain the original natural environment because they do not get tourism benefits and the fundamental interests of the two conflict. Villagers engaged in the tourism business also compete for tourists. Some families had the advantage because they started early, updated their facilities and equipment more quickly, had various business methods and soliciting routes, and formed a better cooperation model with government departments. These early adopters monopolize the tourists, while other villagers' farm hotels only benefit during holidays when there are more tourists.

\section{Interactions between Rural Tourism Communities}

The Longji Scenic Area is large, and each scenic spot has obvious homogeneity. To maximize the economic benefits of each village, there have also been instances of public resource seizure, customer source competition, disorderly competition, and low-price competition. In general, the institutional factors affecting rural community participation can be divided into formal and informal institutions.

Formal institutions that affect RTCs' participation in RT development mainly include land management institutions, grass-roots autonomous institutions, tourism industry management institutions, and vacation institutions. Many informal institutions in RTCs affect the decision-making of community actors, including clans, folk authority, village rules and regulations, traditional ideas (including collectivism, conservatism, fengshui, etc.), and values.

\section{ROLES OF LOCAL INSTITUTIONS ON RT IN DAZHAI}

It has contributed to local development, and enables Dazhai community to receive benefits from tourism industry, namely, it can be an effective approach for poverty alleviation in rural areas. Local community involvement in tourism development shows 
sustainable tourism and advocates tourism as a vehicle of local development (Keyim, 2012) .

The local governments and related institutions in Guilin have make any efforts to support the development of tourism, aiming to create employment and income and make a sustainable contribution towards the well-being of the people in local communities. Connected with the former chapters, the author analyzed the roles of local institutions in Guilin as following, that may act on the development of rural tourism, from the perspectives of political, economy, culture, society, and environment, which can be seen in the following figure:

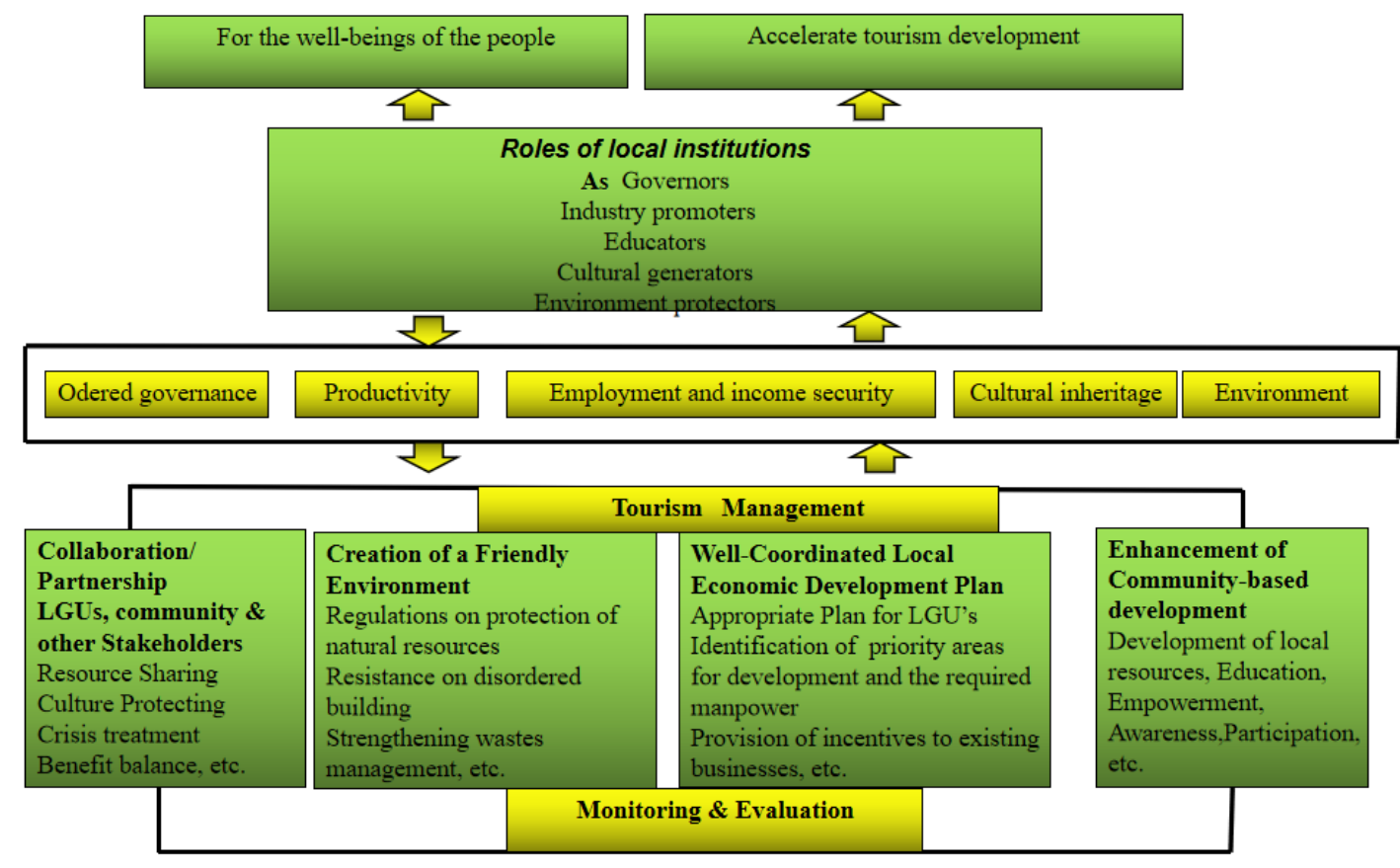

Figure 5. Roles of local institutions in Dazhai

\section{As Governors}


In recent years, several policies (which have been mentioned in Chapter I) have been issued and implemented by local governments (including the provincial, municipal, and prefectural levels) for RT in Guilin. The policies also stressed the responsibilities of LGUs in the effective implementation of poverty alleviation. Local institutions in Guilin have been acting as good governors toward sustainable development. Good governance includes transparency (availability of information, such as rules and regulations), participation, and accountability (or the sense of ownership) by the various stakeholders in their conscious efforts to contribute to solving problems (Atienza, 2011).

RT has been strengthened by obligations to the overall revitalization of rural areas in Guilin. Residents rely on the advantages of scenic resources to carry out tourism-related activities. At the same time, RT also solves the problem of women based in the home, elderly, and children and improves farmers' life satisfaction. Moreover, the convenience of transportation, communication, and other infrastructure has greatly increased destinations' accessibility.

Dazhai was once a poor mountainous area. To improve the poverty situation, the government dispatched poverty alleviation work teams to help poor households develop tourism-related industries, such as growing poultry, to achieve the poverty alleviation target. However, since the main causes of poverty are lack of technology and insufficient development capacity, not all villagers can completely eliminate poverty. Apart from receiving a certain amount of compensation, they have not fundamentally improved their economic situation.

How institutions are embedded in the development of RT, but conflicts still exist among different stakeholders in Dazhai. Tourism-related rules and laws pertain to LGUs, NGOs, the private sector, and RTCs. The participation or non-participation of these sectors significantly affects the success of RT programs. To better coordinate the relationship among various stakeholders, local institutions have taken actions to promote the implementation of RT programs. For example, the Longsheng prefectural government mandated the LJSSAO in the special management of natural resources. Those who violate relevant rules and laws related to building houses would be sanctioned. Under the leadership of local governments, related sectors and the residents have improved their awareness of environmental protection.

On the other hand, the tourism market has also been standardized, eradicating some chaos in business activities. The intentions of these policies are good, and the government has worked hard to coordinate. Companies have improved management, and other business entities and villagers have actively cooperated. It is still, however, traditional top-down governance. Despite the presence of the policies, the "centralization" of tourism management has continued as before. Thus, allegations of corruption among local government officials and monopoly of certain tourism enterprises still surface.

\section{As Industry Promoters}


To better achieve industrial integration, the ethnic villages in the Longji Scenic Area have developed from a single-industry structure dominated by agriculture at the beginning to one now dominated by tourism, supported by handicrafts, specialty agriculture, and other industrial chains. The Dazhai community was once a poor mountain village whose per capita income was less than CNY 700 before 2003 when it officially opened to tourists to showcase terraced farming culture.

Previous discussions show that the projected increase of the benefits from the dividends from 2003-2019 in the community has broadened the gap between the rich and the poor; the rich are getting richer while the poor are getting poorer. On the other hand, considering the characteristics of the Dazhai community, the gap can be managed with limited cost by providing livelihood while preserving ethnic culture. According to the interviews with some of the villagers, although special food and cosmetic products (e.g., grain wine, tea, pepper, fruits, meats, and shampoo) have been developed by the villagers themselves, these lack market-based policy instruments, such as an incentive program, to stimulate these innovative approaches, facilitate scaling up, and encourage community participation.

\section{As Cultural Inheritors}

If culture is the essence of a nation, then tourism is the media of cultural communication. Local institutions in Guilin, especially in the minority areas, advocated integrating culture generation with the development of RT, which is a part of cultural revitalization. In 2016, the Longji Terraces was selected as a national research and tourism demonstration base, being the only unit in Guangxi to receive this honor.

To strengthen the protection of cultural relics and traditional ethnic villages and enhance the cultural self-confidence of the villagers, local governments integrated ethnic culture, farming culture, and family traditions and precepts into RT planning. Along with this were protection and inheritance of ethnic minorities' intangible cultural heritage, such as special food, construction techniques, terrace farming techniques, rice cultivation, and camellia production techniques.

However, these are only limited to a few villagers. Not all villagers are familiar with these, and there is no designated inheritor tasked with sustaining these traditional cultures because young people leave the village to work in urban areas. However, it has been seen that the Dazhai community has its way of protecting and enriching its culture so that villagers can get extra benefits while sharing their traditional practices with their visitors. On the other hand, with the support of the Longsheng government, several rural public cultural service facilities, such as farmhouses and ethnic theaters, have been established to enrich the villagers' spiritual lives. Only a few villagers, however, have desired to patronize them.

\section{As Educators}


At present, the community is intensifying vocational quality education for its rural labor force by increasing industrial support and increasing investment in infrastructure construction. Vocational education provides farmers with more information and professional skills and helps increase their confidence. Through continuing education and training, the knowledge of residents can be improved. Many policies have been issued for continuing education and skills training. There have been a series of training for skills improvement since 2005. The Longsheng Bureau of Human Resources and Social Security and the BA have successively launched training courses for farmers on agricultural machinery maintenance and repair, aquaculture, agriculture, and construction safety. Other courses were on cooking, infant and child care, elderly care, fire safety, and RT management.

\section{As Environment Protectors}

The sustainable development of RT must drive local development, and more importantly, protect the ecological environment on which it depends. After the unified development and operation of the Longji Terraces, the management process included sanitation management, which strengthened the villagers' environmental protection awareness.

Under the guidance of the Longsheng County Government and the LJSSAO, the residents' environmental protection awareness in the villages has been greatly improved. The LJTDC has set up sanitation supervision and inspection in the core scenic spots, increased investment in sanitation facilities, and provided trash bins for garbage segregation. These can keep the villages clean and tidy, protect the terraces, and effectively maintain the area's natural environment.

In the analysis of the roles of local institutions, focusing on the five dimensions (political, economic, cultural, social, and environmental) of RT, it can be seen that local institutions can act as governors, industry promoters, cultural inheritors, educators, and environment protectors in Dazhai.

\section{CONCLUSION AND IMPLICATIONS}

As illustrated in former parts, local government and Longji tourism development company (generally as monopoly) played various dominant roles during the socioeconomic development through rural tourism in Longji Terrace scenic spots, though there exist local small rural tourism businesses and external competitors. The results of the study revealed that Dazhai adopts a management system that is compliant to the $<$ Guilin's overall tourism plan (2001-2020)> which utilized a top-down method approach in the implementation of its policies, structures, coordination mechanism and program implementation. However, as long as the political system is only top-down, then no change is likely to happen. For self-reliance or in-dependency to be translated into an effective management strategy, community participation and engagements must be encouraged. Moreover, external factors like political and social consequences and other social dynamics 
that lie within the LGUs, key agencies and authorities, should be considered for a holistic process (UN, 2005).

Results show that the management systems and protocols of Guilin City, have little or no room for direct interaction between the main guidance of policy, which directly affected the tourism development of the community.In addition, decision-making emanating from the very beginning have been found to towards the lower level residents without any alteration or modifications, which, can be mastered only among the lead agencies. The LGUs (BTCS, the OTPA, the LJSSAO, the BARA, the BEEP are the main planners and decision makers. It also revealed that the LJTDC is the monopoly company in this area. NGOs help express voices but not that completed. But the community is actually not well-involved. Only the community managers or the members of the CPC branch in the community can be representatives expressed the voices of the residents.

Thus, it shows that local institutions as a system highlighting the effective functioning and working together involved to deliver these services toward the LD in operating RT. However, it has not been translated in replication at the community levels. This has been confirmed by the respondents that the current set-up, although effective at some points, has disregarded their capacities to function and adapt as the primary actors.

Similarly, in terms of the existing management system, the respondents expressed that although the government officials' efforts are evident and appreciated by the local residents, there are still areas that need improvement to empower the individuals and the communities as a whole in building its resilience. Since they hope management programs can be transformed from the current "top-down" to a localized and participatory approach by involving the community and making the individuals as the core of tourism development in collaboration with the different sectors, agencies under the guidance of appropriate institutional mechanisms.

In Guilin City's RTCs, the approach to its sustainable development must consider the integration of participation and management cycle. The community's adaptation practices greatly influence the outcomes of tourism development: (1) participation awareness leads to active actions if effective development and management is implemented; (2) partnership measures and coping possibilities should be linked more effectively to provide a more context-specific approach; (3) coordination should be given in the process; and (4) training and skills to ensure alertness and precision of tourism responses should be encouraged.

\section{LITERATURE CITED}


ERIA and OECD (2014), 'Institute Framework' in ERIA SME Research Working Group (ed.), ASEAN SME Policy Index 2014-Towards Competitive and Innovative ASEAN SMEs, ERIA Research Project Report 2012-8, pp.13-21. Jakarta: ERIA and OECD.

FLYVBJERG B. (2006). Five misunderstandings about case-study research. Qualitative Inquiry.

THOMAS P.HUGHES.(1987). Evolution of the large technical system. MIT press:Cambridge, MA. http://www.f.waseda.jp/sidoli/Hughes_1987.pdf.

LI, Y.P., (2004). Exploring Community Tourism in China: The Case of Nanshan Cultural Tourism Zone. Journal of Sustainable tourism12:3, 175-193.

LIMPHO LEKAOTA,(2014).Perceptions On Local Communities' Role And Awareness In Rural Tourism Development: A Case Study From Lesotho. Phd Thesis In Tourism Management,University Of Pretoria.

LUO, J. (2018),Research on the "Longji Model" of Ethnic Cultural Tourism. Mater Thesis from Guilin University of Technology.(Chinese translated into English Version).

MANWA, H., and MANWA, F. (2014). Poverty Alleviation through Pro-Poor Tourism: The Role of Botswana Forest Reserves. Sustainability, 6, 5697-5713.

NORTH, D. C. (1990). Institutions, Institutional Change, and Economic Performance. Cambridge, MA: Cambridge University Press.

NORTH, D. C. (2000). Understanding institutions. In C. Ménard, Institutions, Contracts and Organisations (pp. 7-10). Cheltenham: Edward Elgar.

PARHAD KEYIM, (2012).Number 12 Autumn 2.Government roles in rural tourism development: a case from Turpan.Tourism Today.

REPORT of the APO Seminar on Role of Local Communities and Institutions in Integrated Rural Development held in Islamic Republic of Iran, 15-20 June 2002 (ICD-SE-301),edited by Dr. Chandrasekera M. Wijayaratna, Agricultural/Natural Resources Economist, Institutional Strengthening Specialist, Auckland, New Zealand. Asian Productivity Organization, 2004.

PAGE, S.J.and THORN, K.J. (1997) .Towards sustainable tourism planning in New Zealand: public sector planning responses. Journal of Sustainable Tourism 5(1), pp. 59-77.

UNITED NATIONS.(2005). The Millennium Development Goals Report. Accessed through https://unstats.un.org/unsd/mi/pdf/MDG\%20Book.pdf

ATIENZA, A. VELLA(2011). Review of waste waste management in the Philippines: initiate to promote waste segregation and recycling through Good governance. Economic Integration And Recycling in Asia: An Interim Report. Institute of Developing Economies.

ZAINAL, Z. (2007). Case study as a research method. Jurnal Kemaunistaa bil. 9 June. Retrieved from http://psyking.net/ htmlobj-3837/ case study_ as_a_research_ 
method.pdf.

ZHENG YF. (2016), Institutional Embeddedness: A Comparative Study of Tourism Participation of Two Rural Communities in Danxia Mountain. Master Thesis from Ji'nan University(Chinese translated into English Version).

$<$ Guilin's overall tourism plan (2001-2020) > which utilized a top-down method approach. Retrive from: http://www.guilin.gov.cn 